Section Editors

David C. Spencer, MD

Steven Karceski, MD

Steven Karceski, MD

\title{
Trigeminal nerve stimulator
}

\section{A new treatment for seizures?}

WHAT DID THE AUTHORS STUDY? In their article "Randomized controlled trial of trigeminal nerve stimulation for drug-resistant epilepsy" (Neurology 2013;80: 786-791), Dr. DeGiorgio and colleagues studied the safety and effectiveness of a new kind of treatment for seizures. They used a new device called a trigeminal nerve stimulator (TNS). The device is electronic, and sends small electrical impulses through the skin, using small "stick-on" electrodes. These impulses go to a nerve in the face called the trigeminal nerve. The impulses are then transmitted back to deep parts of the brain where they help to decrease seizures.

The idea of TNS is not new. Animal studies have shown that sending small electrical impulses to the trigeminal nerve (and other nerves in and around the face) helps to reduce seizures. The exact way that this works is not clear, though there is much research in this area. In animal studies, when TNS was used, seizures decreased by $36 \%$ to $58 \%$.

HOW WAS THE STUDY DONE? This study was challenging to do. Each patient had to learn how to use the device. Patients also needed to know where and how to put on the "sticky" electrodes. In order for it to work, each person used the TNS for at least 12 hours each day. Each person with seizures was assessed before going into the trial, and their seizures were very carefully followed through the course of the treatment. Their seizures were assessed at the 6-week, 12-week, and 18-week time points.

In addition, each person answered questions (on a tool designed to evaluate mood called the Beck Depression Inventory) about their mood. This was assessed at the same time as the seizures, at 6,12 , and 18 weeks. The reason for this is that many people with difficultto-control seizures also have mood problems like anxiety or depression. Many of the treatments that are used for seizures also improve mood. Dr. DeGiorgio and his colleagues wanted to see if a device like this might also help a person's mood. In other words, if a person had both epilepsy and depression, a treatment like this might help both at the same time.

In order to know how effective the device was, Dr. DeGiorgio needed 2 groups of people. In one group, high stimulation was given. In the other, a much lower stimulation was given. This is different than other treatment trials, where a medicine is compared with a placebo (or "sugar pill"). When studying a device, there is no way to give a fake stimulation. Because of this, the study compared people who received high vs low stimulation. High stimulation was set at $100 \mathrm{~Hz}$ (100 pulses each second). The low-stimulation group received $2 \mathrm{~Hz}$ (2 cycles per second) stimulation.

WHO WAS IN THE STUDY? There were 50 people in the study. Twenty-five were in the high-stimulation group and 25 were in the low-stimulation group. Because the study was done in Southern California (the Los Angeles area), the people all lived in that area of the United States. They all had a specific kind of epilepsy called partial epilepsy. They all had more than 2 seizures each month before starting the treatment. On average, the people in the groups had tried 3 or more seizure medications before trying TNS. They had had epilepsy for more than 20 years.

WHAT WERE THE RESULTS? Fifty people were enrolled in the study, and 42 completed the treatment. The most common side effects of stimulation were anxiety (4\%), headache $(4 \%)$, and skin irritation $(14 \%)$ from the skin electrodes. There were no serious side effects.

Overall, people in the high-stimulation group did better as compared to those who had the low stimulation. In the high-stimulation group, about one-third (30.2\%) experienced a reduction of seizures by $50 \%$ or more. This was compared to the low-stimulation group, where about one-fifth $(21.1 \%)$ had seizures that were reduced by $50 \%$ or more. In other words, both groups received stimulation. The authors found that more stimulation resulted in a bigger change in seizures. They also found that in the high-stimulation group, the longer TNS was used, the greater likelihood there was a good response.

In a similar way, both groups experienced an improvement in mood. As with seizures, there was a greater change in the high-stimulation group as compared to the low-stimulation group. One interesting observation was that the change in mood did not depend on the change in seizures. In other words, some people noticed that their mood was better even if their seizures had not changed very much.

WHAT DOES THIS MEAN FOR PEOPLE WITH EPILEPSY? We still have much to learn about treatments like this. However, a study like this helps to better 
understand some of the benefits (and problems) of new treatments for seizures. More information is needed, and a larger multicenter study is planned. By looking at a larger group of people, doctors can develop a clearer understanding of how a treatment like this can help. This kind of treatment may still be many years away for people with seizures. However, it is because of studies like this that ideas can become treatments. 
WHAT IS A SEIZURE? Nerve cells in the brain send electrical and chemical (called neurotransmitters) signals to each other at all times. When an abnormal electrical signal is sent, it sometimes causes other brain cells to send abnormal signals as well. If enough of these signals occur, it results in a seizure.

WHAT IS EPILEPSY? Epilepsy is not one illness. There are many kinds of epilepsy. Just as there are many kinds of epilepsy, there are many kinds of seizures. The definition of epilepsy is that a person has had 2 or more unprovoked seizures in his or her lifetime.

One way to think of this is that the brain works like an orchestra. There are different sections in an orchestra, each with its own instruments. Although each instrument plays its own part, it is only when they all play together that complex music is made. While playing, each member of the orchestra has to listen to the other members. As a team, playing together and listening to one another, the best music is made.

However, what if one person began playing a different tune? At first, no one would notice that someone was playing the "wrong" tune. Nearby orchestra members would become confused: which tune were they supposed to play? As more members of the orchestra began playing the "different" tune, it would eventually become noticeable. At some point, the "different" tune might become louder than the original music.

This is similar to how a seizure gets started, and keeps going. The nearby brain cells start playing the wrong tune, and they encourage other brain cells to do the same thing. Eventually, a person cannot stay aware of what is going on around him or her because too many brain cells are busy doing something else (having a seizure).

HOW IS EPILEPSY DIAGNOSED? The doctor will need to know as much as possible about what happened immediately before, during, and after the seizure. How often do the seizures occur? Is there a warning sign? Does the person remember anything about the seizure? All of these questions help the doctor to better understand the kind of seizures and the kind of epilepsy that the person is experiencing. In addition, asking someone who has seen the seizures to describe them can provide valuable information. If the patient does not remember the seizures, the observer may provide information that the patient may not know.

Medical testing can also help to better understand a person's seizures. Electroencephalography (EEG) is a simple and painless study that records the brain's electrical activity. The brain waves are picked up by tiny wires that are taped to the person's head. Specific brain wave patterns may be noted during or between seizures in patients with epilepsy. These patterns provide critical information about the person's epilepsy, and often help with the diagnosis.

Imaging studies are critical in understanding the cause of a person's seizures. The 2 most common studies are MRI and CT. These scans create pictures of the inside of the brain, and are helpful in locating tumors, scars, or other abnormalities that may cause seizures.

HOW ARE SEIZURES TREATED? There are many treatments for seizures. Medicines are tried first. If these do not work, a doctor may consider special diets, brain surgery, or devices for the treatment of seizures. Usually, the physician tries to stop all seizures while causing no side effects. By telling the doctor about problems you experience while on a medication (or any treatment), together you will make the best choice of treatment.

\section{FOR MORE INFORMATION}

AAN Patients and Caregivers site

http://patients.aan.com/go/home

Citizens United for Research in Epilepsy (CURE)

http://www.CUREepilepsy.org

Epilepsy Foundation

http://www.epilepsyfoundation.org

National Council on Patient Information and Education

http://www.talkaboutrx.org 


\title{
Neurology
}

\author{
Trigeminal nerve stimulator: A new treatment for seizures? \\ Steven Karceski \\ Neurology 2013;80;e95-e97 \\ DOI 10.1212/WNL.0b013e3182895647
}

This information is current as of February 25, 2013

Updated Information \&
Services

Subspecialty Collections

Permissions \& Licensing

Reprints including high resolution figures, can be found at: http://n.neurology.org/content/80/9/e95.full

This article, along with others on similar topics, appears in the following collection(s):

All Epilepsy/Seizures

http://n.neurology.org/cgi/collection/all_epilepsy_seizures Epilepsy monitoring

http://n.neurology.org/cgi/collection/epilepsy_monitoring_

Information about reproducing this article in parts (figures,tables) or in its entirety can be found online at:

http://www.neurology.org/about/about_the_journal\#permissions

Information about ordering reprints can be found online:

http://n.neurology.org/subscribers/advertise

Neurology ${ }^{\circledR}$ is the official journal of the American Academy of Neurology. Published continuously since 1951, it is now a weekly with 48 issues per year. Copyright (C 2013 American Academy of Neurology. All rights reserved. Print ISSN: 0028-3878. Online ISSN: 1526-632X.

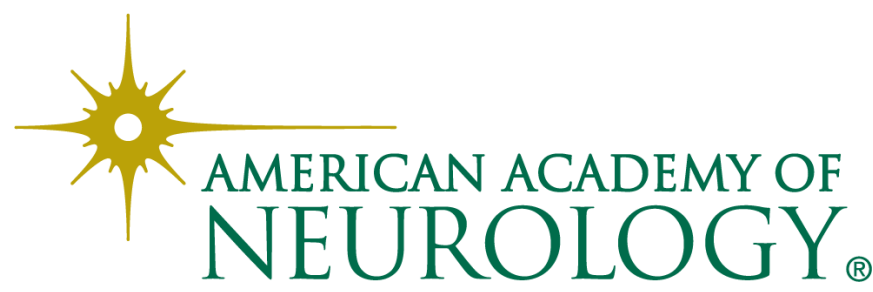

